\title{
A financial evaluation of price formulae
}

\author{
J.J. Doppegieter and I.J. Lambrechts \\ Department of Business Economics, University of Stellenbosch, Stellenbosch
}

This is the second in a series of four articles on price formulae/determination. In the first a simulation model was developed and the criterion of evaluating the model, the internal rate of return, was introduced. In this article two price formulae are simulated and analysed in accordance with principles discussed in the first article. Significant differences emerge between the two formulae. The internal rate of retum of formula $B$ (which is expressed in terms of replacement values) is continuously more than $100 \%$ higher and more stable than that of formula $A$ (which is expressed in terms of historical values). It also appears that it can be misleading to judge the profitability of a price formula against the allowed rate of profitability. The adequacy of the price formulae for inflation is judged by examining the internal rate of return in a situation with and without inflation and by calculating the ratio between depreciation allowed and replacement investments. Finally, the effect of the formulae on financial structure is analysed by calculating a liquidity (based on cash flow) and a solvability ratio. In conclusion, it appears that formula $B$ is superior to formula A, mainly as a result of differences between the price formulae.

S. Afr. J. Bus. Mgmt. 1985, 16: $98-102$

Hierdie is die tweede in 'n reeks van vier artikels oor prysformules/- bepaling. ' $n$ Simulasiemodel is in die eerste ontwikkel en aandag is geskenk aan die kriterium van beoordeling, naamlik die interne rentabiliteit. In hierdie artikel word twee prysformules gesimuleer aan die hand van beginsels wat in die eerste aflewering behandel is.

Belangrike verskille tussen die twee formules kom na vore. Die interne rentabiliteit van formule $B$ (wat in terme van vervangingswaardes uitgedruk is) is voortdurend meer as $100 \%$ hoër en ook meer stabiel as dié van formule $\mathrm{A}$ (wat in terme van historiese waardes uitgedruk is). Dit blyk ook dat dit misleidend kan wees om die rendement van 'n prysformule te beoordeel in terme van die toegelate rentabiliteit. Die voorsiening van die prysformules vir inflasie word beoordeel deur te kyk na die interne rentabiliteit met en sonder inflasie asook na die verhouding tussen toegelate waardevermindering en vervangingsinvesterings. Ten slotte word die invloed van die formules op finansiële struktuur ontleed deur 'n likwiditeits- (gebaseer op kontantvloei) en soivabiliteitsverhouding te bereken. Dit blyk dat formule $B$ tot beter finansielle resultate as formule A lei, hoofsaaklik as gevolg van verskille tussen die twee formules.

S.-Afr. Tydskr. Bedryfsl. 1985, 16: 98- 102

\section{J.J. Doppegieter* and I.J. Lambrechts}

Department of Business Economics, University of Stellenbosch, Stellenbosch, 7600 Republic of South Africa

*To whom correspondence should be addressed

\section{Introduction}

In the first article in the series we introduced an approach to evaluate price formulae. Amongst other things a computer model designed to simulate price formulae was developed and a theoretically more acceptable criterion of profitability, the internal rate of return, was introduced in order to judge the adequacy of formulae. In this article, the second in a series of four, we will analyse three financial aspects of price formulae, viz. the analysis of the profitability, the provision for inflation, and an analysis of the financial structure.

\section{Research method}

In the first article two price formulae, $\mathrm{A}$ and $\mathrm{B}$ (which are applicable to companies $A$ and $B$ ), were introduced. Subsequently, two models, A and B, were developed to simulate and to analyse these two companies. In the simulation of the two companies the balance sheet and relevant items of the income statement were taken into account. As far as the analysis of the companies was concerned, some selected financial criteria and ratios were incorporated.

The model parameters in Table 1 were based partly on company/industry circumstances and partly on predictions of certain external factors.

For the purpose of this article one run of each computer model was produced in order to examine the financial behaviour of each company and the consequences of the identified differences.

\section{Research findings}

Analysis of profitability

Our foremost concern in evaluating price formulae is profitability. In the previous article it was concluded that the conventional profitability (the accounting rate of return) based on annual financial statements is subject to certain shortcomings. Hence, a more acceptable criterion, the internal rate of return (discounted cash flow rate of return), was introduced.

In Figure 1 the internal rates of return of companies $A$ and B are illustrated graphically. As a result of the differences between the two companies, interesting differences between the two internal rates of return can be observed.

The internal rate of return (after taxation) of company $A$ is $17,7 \%$ (in year 1) and fluctuates, as a function of time, between $16,9 \%$ and $18,6 \%$. In contrast, the internal rate of return (after taxation) of company B is $36,6 \%$ in year 1 and increases subsequently to $37,1 \%$ in year 11 after which it remains stable.

Although company A's internal rate of return is, as a 
Table 1 Parameters to simulate and analyse companies $A$ and $B$

\begin{tabular}{|c|c|c|}
\hline Model parameter & $\begin{array}{c}\text { Model A } \\
\text { Historical } \\
\text { Cost }\end{array}$ & $\begin{array}{l}\text { Model B } \\
\text { Replacement } \\
\text { Cost }\end{array}$ \\
\hline 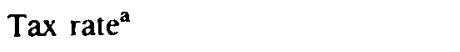 & 46 & $46^{e}$ \\
\hline Average interest rate ${ }^{a}$ & 20 & 20 \\
\hline Growth rate ${ }^{\mathrm{a}}$ & 5 & 5 \\
\hline $\begin{array}{l}\text { Inflation rate (i.r.o. fixed and } \\
\text { current assets) }\end{array}$ & 14 & 14 \\
\hline $\begin{array}{l}\text { The profitability rate allowed on } \\
\text { capital employed }^{\mathrm{a}}\end{array}$ & $15^{\mathrm{b}}$ & $15^{\mathrm{c}}$ \\
\hline $\begin{array}{l}\text { Percentage of capital require- } \\
\text { ments financed by equity }\end{array}$ & 30 & 30 \\
\hline Average initial allowance & 10 & $0^{d}$ \\
\hline Average investment allowance & 28 & $\sigma^{d}$ \\
\hline Return on investments & 10 & 10 \\
\hline Dividend coverage ratio & 2,5 & 2,5 \\
\hline Initial fixed assets & 80 & 75 \\
\hline Initial current assets & 20 & 25 \\
\hline Initial equity & 60 & 60 \\
\hline Initial long-term debt & 10 & 10 \\
\hline $\begin{array}{l}\text { Initial short-term interest-bearing } \\
\text { debt }\end{array}$ & 20 & 20 \\
\hline $\begin{array}{l}\text { Initial short-term non-interest- } \\
\text { bearing debt }\end{array}$ & 10 & 10 \\
\hline
\end{tabular}

These model parameters are fully flexible, i.e. adaptable yearly.

Before tax.

After tax.

${ }^{d}$ Not applicable to company $B$

- The statutory tax rate is $46 \%$. However, owing to taxation allowances other than initial and investment allowances, the effective rate decreases to $22 \%$ (the latter $\%$ has been used in the analysis)

function of time, reasonably stable, company B's internal rate of return proves to be even more stable.

Most remarkable, however, is the substantial difference between the absolute percentages of the two internal rates of return. For the full duration of the analysis company B's internal rate of return is more than $100 \%$ higher than that of company A. This finding can only be explained by the model differences previously mentioned. In the third article the objective will be to examine to what extent each difference between the two price formulae is responsible for this substantial difference.

Furthermore, if the internal rates of return are compared with the allowed rates of profitability, it appears that it can be quite misleading to use the latter as an important indication of profitability. Company A's internal rate of return (approximately $17 \%$ after taxation) compares with the allowed profitability rate ( $15 \%$ before taxation). Company B's internal rate of return (approximately $\mathbf{3 7} \%$ after taxation) bears very little relation to the allowed profitability rate of $15 \%$ after tax.

Finally, it must be stressed that in evaluating the adequacy of the applicable formulae, the internal rate of return must not be judged in isolation or compared with the internal rates of return of other companies without taking into account the specific business and financial risk of the company involved.

\section{The analysis of the provision for inflation}

Especially in times of high inflation it is important to examine whether the specific formula provides enough compensation for price rises. In respect of this analysis two criteria are used, namely
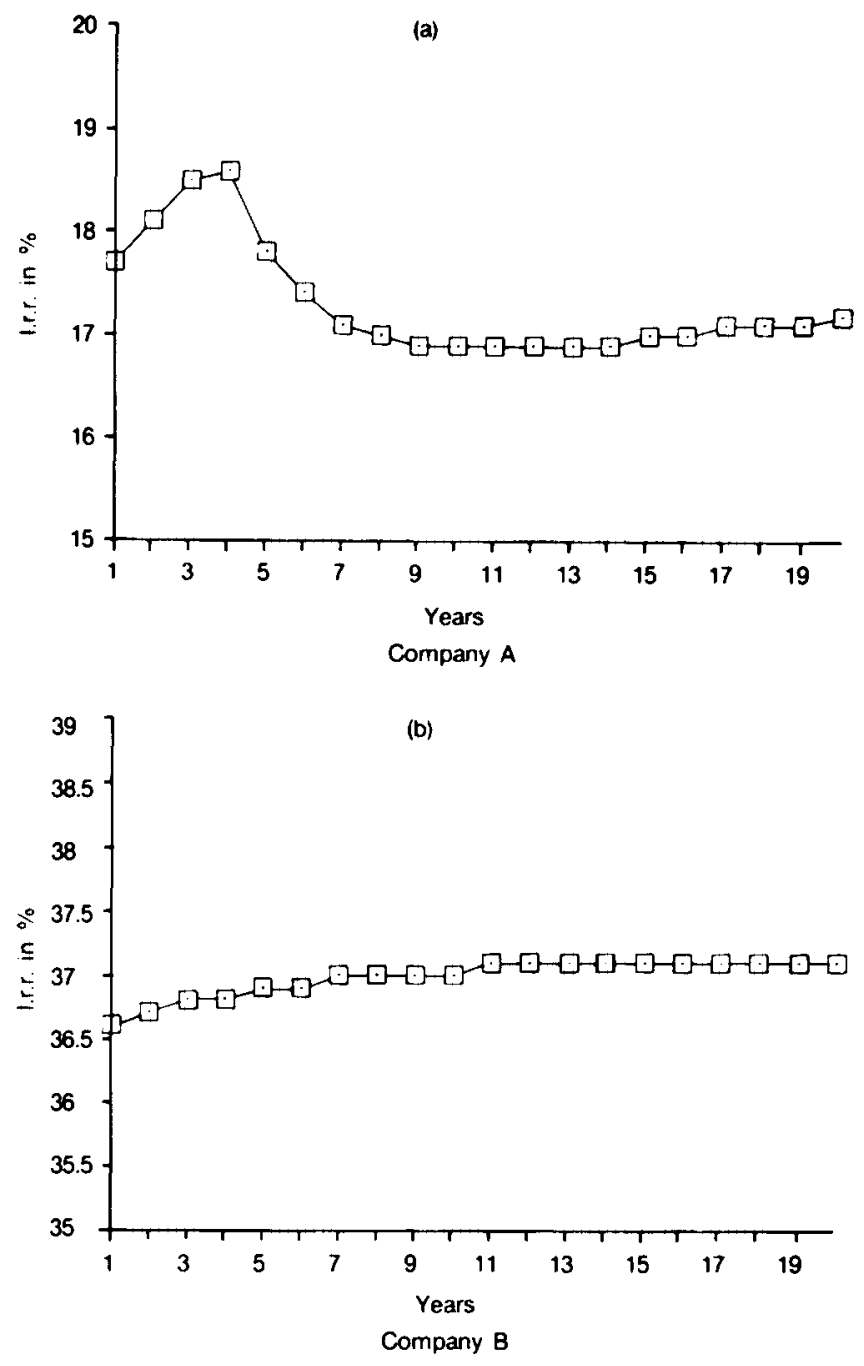

Figure 1 The internal rates of return (i.r.r) after taxation of companies $\mathrm{A}$ and $\mathrm{B}$

- the internal rate of return and

- the ratio depreciation to replacement investments

\section{The internal rate of return}

An indication of the provision for inflation is obtained by comparing the internal rate of return with the rate of inflation.

Given an inflation rate of $14 \%$, formula $A$ appears to allow little provision for inflation in the light of company A's internal rate of return of approximately $17 \%$, especially if one takes into account that the higher cost of replacement and cost of sales are not tax-deductible expenses. Additional depreciation and cost of sales to provide for higher replacement cost are therefore debits against the after-tax income. It should be noted that the 'hedging' effect of financial gearing against the detrimental consequences of inflation is automatically taken into account by the formula. Conversely, formula B allows ample provision, according to company B's internal rate of return of approximately $37 \%$.

This approach, however, produces a somewhat distorted picture of the actual provision, since the growth rate (presumed $5 \%$ ) exercises a similar influence on the internal rate of return as the rate of inflation does. To get a clearer picture, therefore, the impact of inflation on the internal rate of return has to be isolated. This will be done by simulating and analysing two different situations:

- Situation 1:0\% growth and 0\% inflation

- Situation 2:0\% growth and 14\% inflation

In Figure 2 the internal rates of return of companies $A$ and 


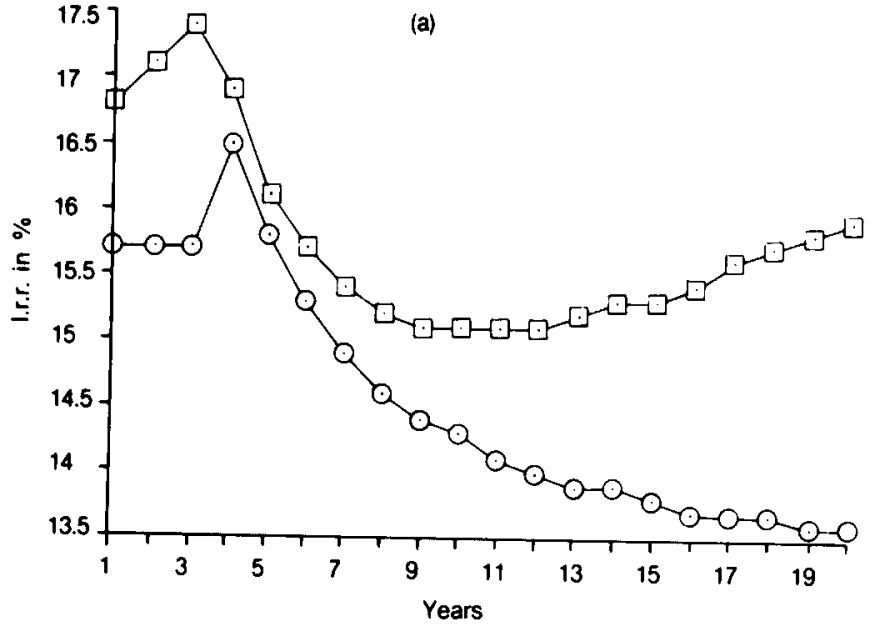

$\square 14 \%$ inflation, $0 \%$ growth $\odot 0 \%$ inflation, $0 \%$ growth

Company $A$

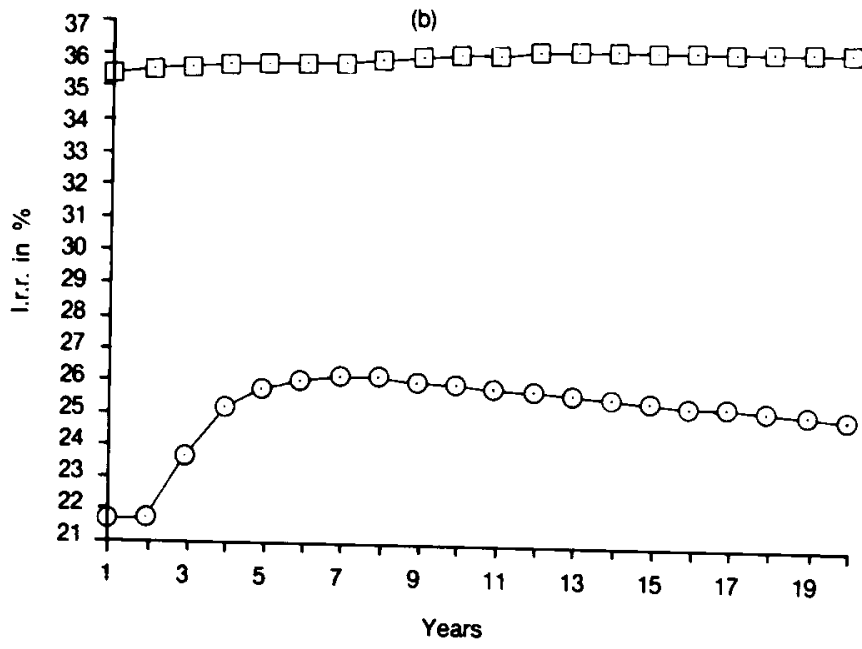

๑14\% inflation, $0 \%$ growth $\odot 0 \%$ inflation, $0 \%$ growth

Company B

Figure 2 The impact of inflation on the internal rates of return of companies $\mathrm{A}$ and $\mathrm{B}$

$B$ in the two different situations are shown.

In model $\mathbf{A}$ the introduction of inflation has a positive, but relatively small effect on the internal rate of return, The effect (compensation) varies between $0,3 \%$ (year 4 and 5 ) and $2,3 \%$ (year 20). The introduction of inflation in model $B$ has, in contrast to model A, a strong positive effect on the internal rate of return, which increases by between $9,2 \%$ and $13,2 \%$. Although this compensation for inflation appears to be substantially higher than that of company $A$, it never provides for a complete adjustment of the internal rate. In other words, the effect of inflation is not entirely carried over to the buyers, probably as a result of the 'hedging' effect of financial gearing.

The reason for the significant difference between the two companies in the compensation for inflation is obvious. Formula $\mathrm{A}$ allows for only one inflation adjustment, i.e. additional depreciation, whereas formula $\mathbf{B}$ also allows the valuation of the fixed assets at replacement value (in contrast with historical cost value) as well as a tax compensation to allow for the non-tax deductibility of additional depreciation.

\section{The ratio depreciation to replacement investments}

This criterion examines the provision for inflation in respect of the fixed assets only. In other words, will the specific formula allow sufficient depreciation in times of inflation to

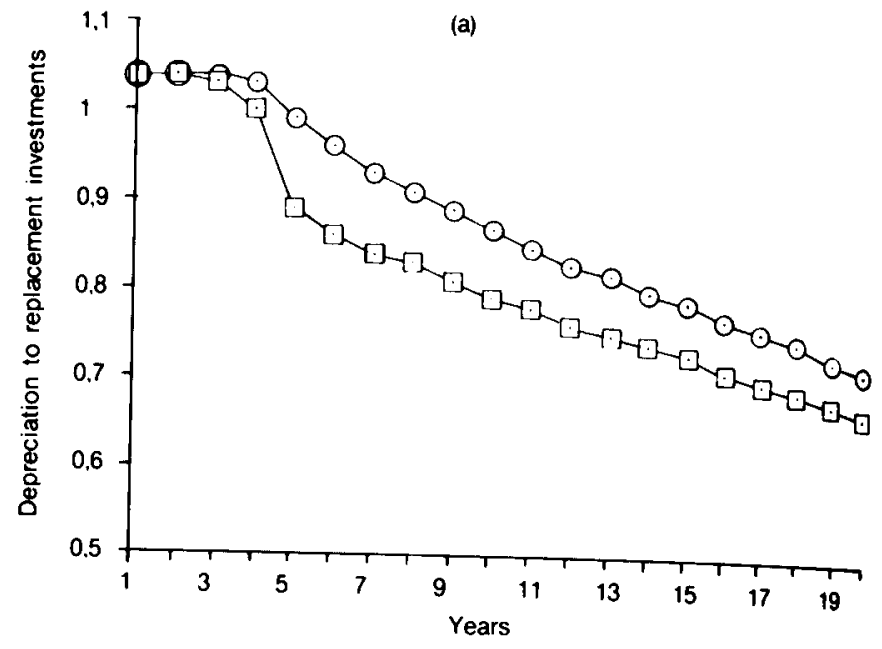

$\square$ Yearly \%

$\odot$ Cumulative \%

Company A

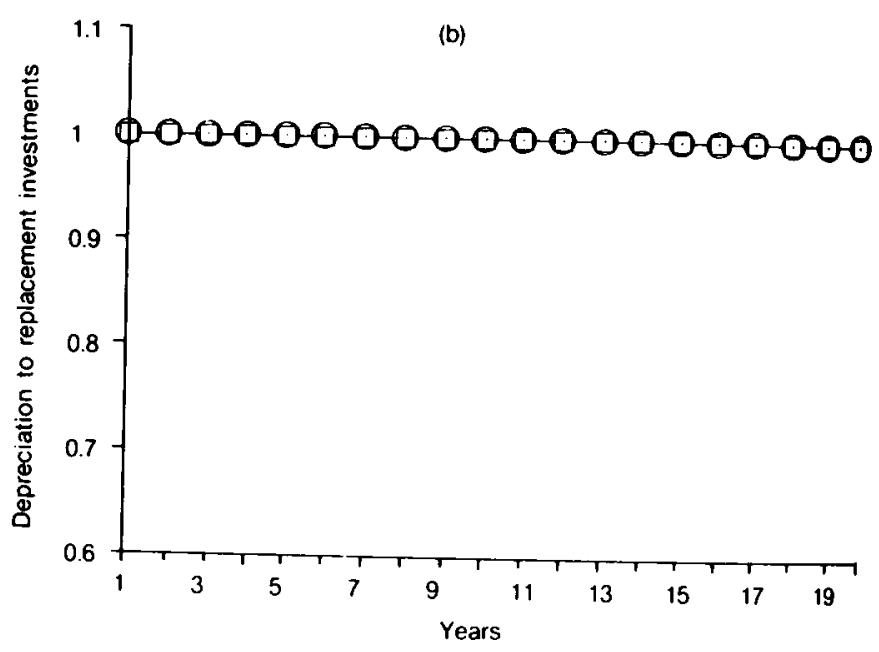

$\square$ Yearly \%

$\bigcirc$ Cumulative $\%$

Company B

Figure 3 The ratio depreciation to replacement investments in companies $\mathbf{A}$ and $\mathbf{B}$

replace fixed assets?

In company $\mathbf{A}$ both the annual and cumulative ratios are 1,04 in year 1 and decrease gradually, as a function of time, to 0,67 and 0,72 respectively (Figure 3 (a)). In company $B$ both ratios remain at 1 during the 20 years of analysis (Figure $3(\mathrm{~b})$ ).

If the ratios equal or exceed 1 , adequate provision is made for the replacement of fixed assets. In company A sufficient provision is only provided on the short term but over the longer term the ratio weakens seriously. In company B the depreciation allowed is sufficient to replace the fixed assets.

The explanation for this difference is found in the fact that the depreciation allowed differs for the two formulae. In company A normal depreciation and an additional depreciation are allowed. In company B an extra tax compensation in respect of the additional depreciation is allowed to provide for the non-tax deductibility of additional depreciation.

\section{Analysis of the financial structure}

Each company or industry which is partially financed with loan capital is subject to financial risk. Two types of financial risk can be distinguished:

(i) The risk of illiquidity, where a company is not able to pay its maturing short-term obligations in the form of interest and amortization of debt. 
(ii) The risk of insolvency, where a company cannot attract additional loan capital.

The two risks in respect of companies A and B are examined separately.

\section{The risk of illiquidity}

In both computer models the ratio cash flow to interest is incorporated to analyse the risk of illiquidity.

The results are illustrated in Figure 4. In company $A$ the ratio fluctuates between 2,5 and 3,5 while in company $B$ the ratio is 4,8 in year 1 and increases progressively to 60,7 in year 20.

The liquidity position of company B compares favourably, especially over the longer term, with that of company $\mathbf{A}$.

Two reasons explain this difference. Firstly, as we saw in the analysis of the profitability, company B generates substantially higher profits and consequently more cash flow than company A. Secondly, as a result of the higher profits, company $\mathrm{B}$ is able to generate more internal funds and needs less loan capital than company $\mathrm{A}$. The obvious result is that company $\mathrm{B}$ has to pay less interest than company $\mathrm{A}$.

\section{The risk of insolvency}

In order to examine the solvency of both companies, the ratio equity capital to total capital was implemented in the computer models (Figure 5).

In company $A$ the ratio fluctuates more or less around

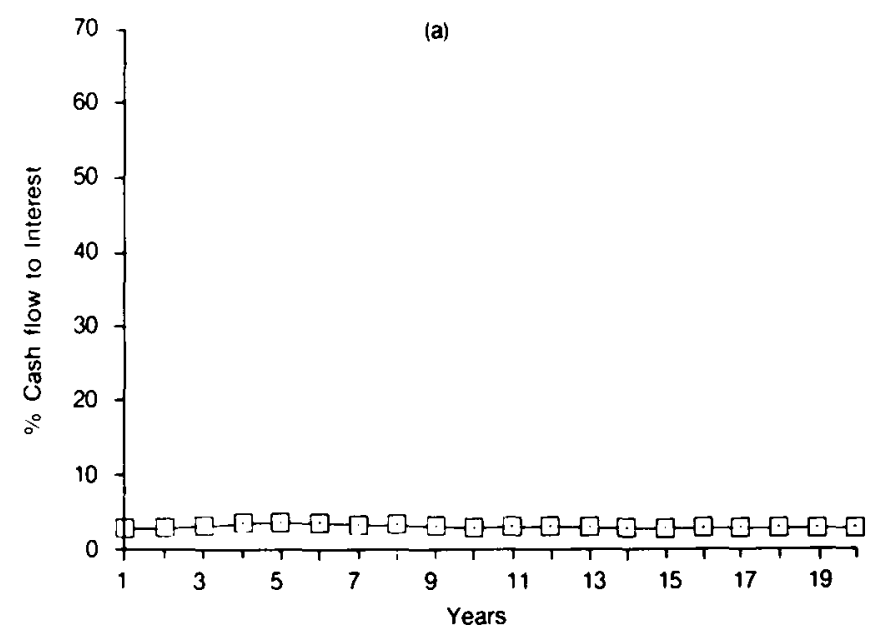

Company A

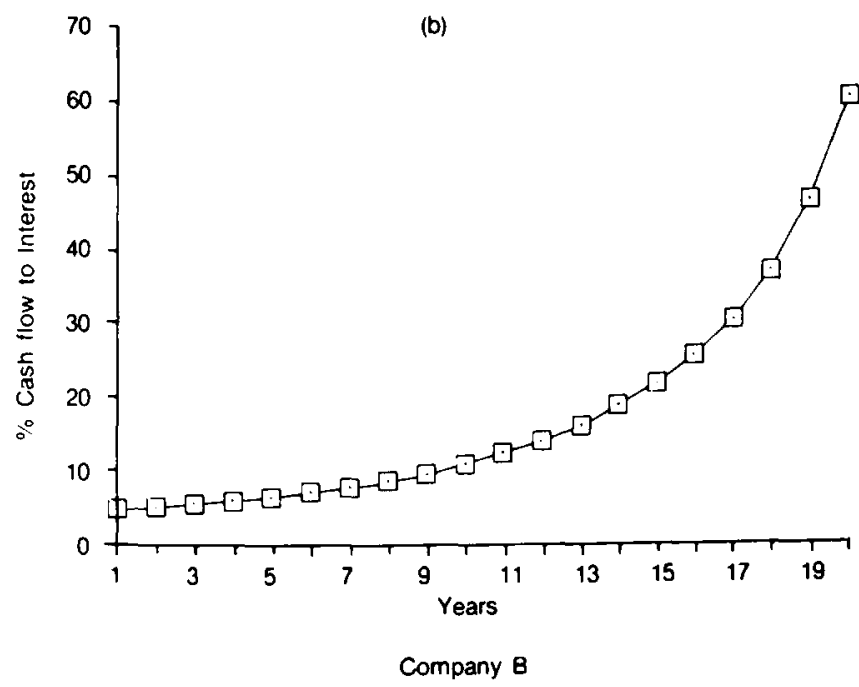

Figure 4 The liquidity of companies A and B, expressed in the ratio: cash flow to interest
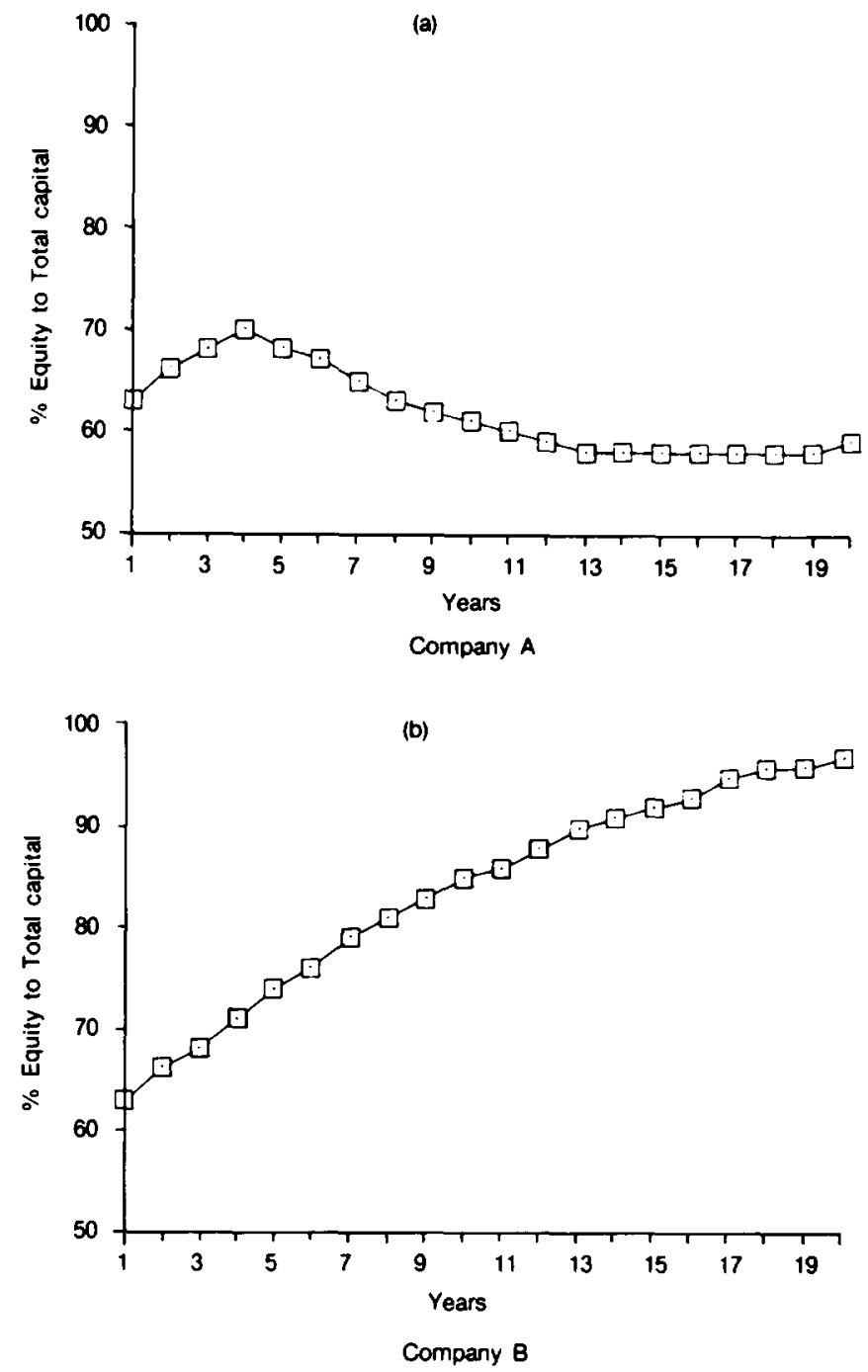

Figure 5 The solvability of companies A and B expressed in the ratio: equity capital to total capital

$60 \%$. In company B the ratio increases gradually from $60 \%$ in the initial year to $97 \%$ in year 20 . Company B's solvency proves to be much better than company A's. Although company A's ratio does not deteriorate in comparison with the initial ratio, the difference with company $B$ is startling, particularly over the long run.

The cause of this difference is again found in differences between the two price formulae. Formula B allows more profit, thereby providing company B with more equity capital (retained earnings) than formula A. Furthermore, because in practice the solvency of a company is directly related to the percentage interest payable, company $B$ will be considered for a lower interest rate than company $A$, thereby augmenting the difference between the liquidity positions of companies $A$ and $B$.

\section{Some further applications}

Firstly, the analysis of profitability could be extended by comparing the internal rate of return with the critical rate of return (the cost of capital). If the internal rate of return exceeds the critical rate of return of the specific company, a satisfactory return would have been provided by the price formula and vice versa.

Secondly, by incorporating the accounting rate of return in the model, the following relations could be analysed:

(i) The relation between the allowed profitability rate and the accounting rate of return.

(ii) The relation between the internal rate of return and the 
accounting rate of return.

Thirdly, in respect of the analysis of the provision for inflation, $a$ sensitivity analysis could be initiated. For example, the effect of marginal changes in the rate of inflation could be analysed by examining the behaviour of all kind of variables, such as the internal rate of return and the capital structure.

Fourthly, in regard to the analysis of the financial structure various additional ratios could be implemented, e.g. the current ratio and the quick ratio.

Finally, a funds position could be introduced in order to study the movement of the funds, which determines the risk and profitability profiles of the company involved, thereby depicting the financial position. It would provide for a more effective, meaningful, and creative means of financial planning and decision-making.

\section{Conclusions}

In this second article two price formulae, A and B, are simulated and analysed in accordance with their respective computer models, described in the previous article. Significant differences emerge between the two companies.

In analysing the profitability, company B's internal rate of return (on average $35 \%$ after tax) is continuously more than $100 \%$ higher than and more stable than that of company $A$ (on average $17 \%$ after tax). Furthermore, by comparing the allowed rate of profitability with the internal rate of return it appears that it can be misleading to judge the profitability of a price formula against this allowed rate of profitability.

In respect of the analysis of the provision for inflation two criteria are used. On examining the internal rate of return in a situation without inflation and subsequently with $14 \%$ inflation, it is found that company B allows much more provision $(13,2 \%)$ for inflation than company $A(2,3 \%)$. When judging the ratio between depreciation allowed and replacement investments, company $B$ is allowed sufficient compensation in regard to the fixed assets.

In addition, on examining the financial structure, company A's liquidity and solvency prove to be notably weaker than that of company B, especially over the long run.

In conclusion, it appears that company B's profitability, provision for inflation, and financial structure compare favourably with that of company $\mathrm{A}$. These differences can be explained by looking at the differences between the two models, which are in essence differences in the two applied price formulae. 